\title{
An Approach to the Total Synthesis of Welwistatin
}

\author{
Thomas J. Greshock and Raymond L. Funk \\ Department of Chemistry, Pennsylvania State University, University Park, PA 16802
}

\begin{abstract}
An approach to the total synthesis of the anti-microtubule agent welwistatin is described. Key transformations include 1) a 7-endo intramolecular conjugate addition reaction of enone 6 to deliver the strained bicyclo[4.3.1]decanone 5;2) a $6 \pi$ electrocyclic ring closure of trienecarbamate 16 followed by oxidation to afford protected aniline 17; and 3) an intramolecular cyclization of acetic acid derivative 18 to give rise to indole 19 .
\end{abstract}

The welwitindolinones ${ }^{1}$ are a fascinating family of indole alkaloids isolated from blue-green algae. Welwitindolinone $\mathrm{C}$ isothiocyanate (welwistatin) is one of the major alkaloids isolated from both Hapalosiphon welwitschii and Westiella intricate $1 \mathrm{a}$ and the structure of the $\mathrm{N}$-methyl congener was secured by X-ray crystallographic analysis (Scheme 1). Moreover, it has been hypothesized that all of these welwitindolinones arise from welwitindolinone $\mathrm{A}$ via epoxidation of the alkene moiety and subsequent cyclization at $\mathrm{C}(4) .{ }^{1 \mathrm{a}}$ It was originally believed that welwistatin reversed P-glycoprotein mediated multiple drug-resistance (MDR). ${ }^{2 \mathrm{a}}$ However, it was later shown that welwistatin is a cytotoxin itself and inhibits the proliferation of SKOV-3 and A-10 cells ( $\mathrm{IC}_{50}, 72$ and $900 \mathrm{nM}$, respectively) and, more importantly, arrests Pglycoprotein-overexpressing MCF-7/AdR cells $\left(\mathrm{IC}_{50}, 130 \mathrm{nM}\right)$ in the $\mathrm{G} 2$ mitotic phase. ${ }^{2 \mathrm{~b}}$ Moreover, immunofluorescence studies of tubulin organization revealed that welwistatin causes dose-dependent disruption of microtubules in intact cells. Additional experimentation suggested that welwistatin does not bind to either the colchicine or taxol sites. ${ }^{2 b}$ Thus, this compound represents a new anti-microtubule agent that may be useful for the treatment of drug-resistant tumors.

The unprecedented ring system, the sensitive vinyl chloride and bridgehead isothiocyanate functionalities, the vicinal quaternary centers and the $\mathrm{C}(16)$ gem-dimethyl substituent conspire to make the synthesis of welwistatin an especially challenging problem. Several synthetic approaches have been described and all of them have in common the elaboration of the complete ring system from an appropriately substituted indole or oxindole. ${ }^{3,4} \mathrm{We}$ present a conceptually distinct strategy for the total synthesis of welwistatin that 1) permits the immediate incorporation of the $\mathrm{C}(12), \mathrm{C}(15)$ relative stereochemistry beginning with an easily accessible substituted cyclohexanone; 2) addresses the early stage construction of the strained bridged bicyclic substructure using our 1,3-dioxin based methodology; 5 and 3) subsequently elaborates the indole/oxindole ring system by exploiting our newly developed annelation sequence. ${ }^{6}$

Our retrosynthetic analysis is outlined in Scheme 1. Indole 1 possesses a fully intact ring system and is suitably functionalized for the introduction of the vinyl chloride, bridgehead isothiocyanate and oxindole functionalities from the respective vinyl triflate, ${ }^{7}$ bridgehead nitrile and indole $3 \mathrm{~d}, \mathrm{e}$ moieties. Indole $\mathbf{1}$ was envisaged to arise from $\alpha$-iodoenone $\mathbf{4}$ through extension of our newly developed indole annelation sequence. ${ }^{6}$ Thus, electrocyclic ring closure 
of trienecarbamate $\mathbf{3}$ and a carbonyl condensation reaction involving the $\alpha$-anilinoacid $\mathbf{2}$ were the expected key bond forming steps. It seemed likely that the $\mathrm{C}(3)$ carbonyl group of diketone 5 could be chemo- and regioselectively enolized in order to sequentially install the vinyl iodide functionality and thence the gem-dimethyl group. We had previously prepared bicyclo[4.3.1] decan-3,10-diones related to dione $\mathbf{5}$ using halide $\mathbf{8}$ as a bromomethyl vinyl ketone equivalent. 5 In this specific application, it was hoped that the kinetic enolate of ketone 7 would undergo axial alkylation from the $\alpha$-face through a chair conformer possessing equatorial vinyl and silyloxy substituents. Alkylation of the enolate from the $\beta$-face through either a chair or boat conformer would be less preferred due to a developing 1,3-diaxial interaction with the silyloxy substituent or a flagpole, flagpole interaction with the methyl group, respectively. ${ }^{8}$ The resulting alkylation product then would be converted to a $\beta$-ketonitrile and heated to effect retrocycloaddition to enone $\mathbf{6}$, the substrate for the intramolecular Michael addition leading to diketone $\mathbf{5}$.

Our synthesis commenced with the preparation of the known ketone 7, easily available from 3 -methylanisole as either the racemate or in optically pure form (Scheme 2). ${ }^{9}$ As expected, alkylation of the enolate derived from ketone $\mathbf{7}$ with allylic bromide $\mathbf{8}$ proceeded diastereoselectively to deliver ketone 9. The tentative stereochemical assignment was confirmed upon cyanation of its regioselective enolate with $p$-toluenesulfonyl cyanide to afford $\beta$-ketonitrile 10 whose coupling constants for the diagnostic ${ }^{1} \mathrm{H}$ NMR resonances, as well as NOE observations, were consistent with the assigned structure. It should be noted that all attempts to prepare the analogous $\beta$-ketoester were uniformly unsuccessful and instead led to the isolation of the $\mathrm{O}$-acylated product. With the correct $\mathrm{C}(12)-\mathrm{C}(15)$ relative stereochemistry now in place, we turned to completion of the bridged bicyclic structure. Thus, thermolysis of dioxin 10 effected a retrocycloaddition to afford enone $\mathbf{6}$ (Scheme 1). Treatment of enone 6 with $\mathrm{Et}_{3} \mathrm{~N}$ in $\mathrm{THF} / \mathrm{MeOH}$ effected a smooth 7-endo intramolecular conjugate addition reaction to deliver the desired bicyclo[4.3.1]decanone $\mathbf{5}$ with no indication of competing epimerization at $\mathrm{C}(15)$.

With the fully substituted bridged bicyclic ring system in hand, we directed our attention toward the preparation of the $\alpha$-haloenone $(\mathbf{4}$, Scheme 1$)$ required for the indole annelation sequence. Concurrent investigations indicated that the bridgehead carbonyl of enone 4 would prove to be troublesome, in particular, during the anticipated electrocyclic ring closure of triene carbamate 3. ${ }^{10}$ Accordingly, ketone 5 (Scheme 2) was regioselectively converted to a silyl enol ether, the problematic bridgehead ketone then was reduced stereoselectively (9:1) with $\mathrm{LiAlH}(\mathrm{O}-t \mathrm{Bu})_{3}$ and the resulting alcohol was protected with TBSOTf to afford the more robust bicyclic compound 11. Since attempts to $\alpha$-iodinate the enone obtained from Sageusa oxidation $\left[\mathrm{Pd}(\mathrm{OAc})_{2}\right]$ of silyl enol ether 11 were unsuccessful, we turned to alternative strategies for the preparation of an $\alpha$-haloenone. It was eventually discovered that the selenide $\mathbf{1 2}$, obtained by treatment of silyl enol ether 11 with $\mathrm{PhSeCl}$ followed by brief thermodynamic equilibration of the resulting diastereomeric $\alpha$-phenylselenoketones $\left(4: 1 ; 12\right.$ :epi) with $\mathrm{Cs}_{2} \mathrm{CO}_{3}$, was a viable precursor to $\mathbf{1 3}$.

Indeed, we were pleased to find that subjection of selenide 12 to excess $\mathrm{NBS}$ in $\mathrm{CCl}_{4}$ cleanly provided the desired $\alpha$-bromoenone 13 (Scheme 3). ${ }^{11}$ It is of interest to note that the epimeric selenide afforded only des-bromo 13 when subjected to these reaction conditions. Following introduction of the gem-dimethyl group by sequential enolate methylations, we turned to the Stille coupling of $\alpha$-bromoenone $\mathbf{1 4}$ with $\alpha$-stannyl enecarbamate $\mathbf{1 5}^{6}$ i $\mathrm{n}$ order to prepare the key electrocyclization precursor, amidotriene 16. We were gratified to discover that upon heating in toluene $\left(110^{\circ} \mathrm{C}, 3 \mathrm{~h}\right)$, triene 16 now underwent an uneventful ring closure to afford a cyclohexadiene that was oxidized in situ with DDQ to furnish the protected aniline 17.

Removal of the BOC group of carbamate 17 with TFA and reductive amination of the resultant aniline with glyoxylic acid provided acid 18. Closure to $N$-acetylindole 19 was then effected 
using the conditions employed in our methodological studies and constitutes the sterically most demanding example of this transformation that we have examined. Although we plan to introduce the bridgehead nitrogen at a later stage in our projected total synthesis, we thought it would be prudent to document the feasibility of this Hofmann-rearrangement-based transformation in such a congested environment. To that end, we found that hydrolysis of the encumbered nitrile could be accomplished with the remarkable Parkins catalyst $\mathbf{2 0} \mathbf{0}^{12}$ to secure the bridgehead amide 21 . It was equally pleasing to discover that the Baumgarten variant ${ }^{13}$ of the Hofmann rearrangement was successful when amide 21 was subjected to $\mathrm{Pb}(\mathrm{OAc})_{4}$ in DMF at $90{ }^{\circ} \mathrm{C}$, thereby providing the most advanced welwistatin total synthesis intermediate, isocyanate 22, reported to date. Thus, it is hoped that indole $\mathbf{1 9}$ is well functionalized for the intensive functional group manipulation phase of our total synthesis endeavor. These studies are underway and will be disclosed in due course.

\section{Supplementary Material}

Refer to Web version on PubMed Central for supplementary material.

\section{Acknowledgement}

We appreciate the financial support provided by the National Institutes of Health (GM28553).

\section{References}

(1). Smith CD, Zilfou JT, Stratmann K, Patterson G, Moore RE. Mol. Pharm 1995;47:241. (b) Zhang X, Smith CD. Mol. Pharm 1996;49:288.

(2)(a). Smith CD, Zilfou JT, Stratmann K, Patterson G, Moore RE. Mol. Pharm 1995;47:241. (b) Zhang X, Smith CD. Mol. Pharm 1996;49:288.

(3)(a). For approaches to the welwitindolinones, seeKonopelski JP, Deng H, Schiemann K, Keane JM, Olmstead MM. Synlett 1998:1105. (b) Wood JL, Holubec AA, Stoltz BM, Weiss MM, Dixon JA, Doan BD, Shamji MF, Chen JM, Heffron TP. J. Am. Chem. Soc 1999;121:6326. (c) Kaoudi T, Quiclet-Sire B, Seguin S, Zard SZ. Angew. Chem. Int. Ed 2000;39:731. (d) Konopelski JP, Deng H. Org. Lett 2001;3:3001. [PubMed: 11554828] (e) Jung ME, Slowinski F. Tetrahedron Lett 2001;42:6835. (f) López-Alvarado P, García-Granda S, Álvarez-Rúa C. Eur. J. Org. Chem 2002:1702. (g) Ready JM, Reisman SE, Hirata M, Weiss MM, Tamaki K, Ovaska TV, Wood JL. Angew. Chem. Int. Ed 2004;43:1270. (h) MacKay JA, Bishop RL, Rawal VH. Org. Lett 2005;7:3421. [PubMed: 16048307] (i) Baudoux J, Blake AJ, Simpkins NS. Org. Lett 2005;7:4087. [PubMed: 16146358](j) For a review, seeAvendano C, Menéndez JC. Curr. Org. Syn 2004;1:65.

(4)(a). For total syntheses of welwitindolinone A, seeBaran PS, Richter JM. J. Am. Chem. Soc 2005;127:15394. [PubMed: 16262402] (b) Reisman SE, Ready JM, Hasuoka A, Smith CJ, Wood JL. J. Am. Chem. Soc. 2006ASAP

(5). Greshock TJ, Funk RL. J. Am. Chem. Soc 2002;124:754. [PubMed: 11817942]

(6). Greshock TJ, Funk RL. J. Am. Chem. Soc 2006;128:4946. [PubMed: 16608316]

(7)(a). By treatment of the corresponding vinyl stannane with $\mathrm{CuCl}_{2}$, seeTakeda T, Kanamori F, Matususita H, Fujiwara T. Tetrahedron Lett 1991;32:6563. (b) Madec D, Férézou JP. Tetrahedron Lett 1997;38:6661.

(8)(a). This analysis is substantiated by several examples of highly diasteroselective C(6) alkylations of related 3,3,4-trisubstituted cyclohexan-1-ones, seeFredrich P, Bohlmann F. Tetrahedron 1988;44:1369. (b) Tomioka K, Masumi F, Yamashita T, Koga K. Tetrahedron 1989;45:643. (c) Kato M, Kosugi H, Ichiyanagi T, Yamabe O. J. Chem. Soc. Perkin Trans. I 1999:783.

(9). Frejd T, Polla M. Tetrahedron 1991;47:5883.

(10). In previous studies we had found that the product of the electrocyclic ring closure of the des-methyl analog of trienecarbamate 3 was thermally unstable and underwent a concomitant vinylogous retroMannich reaction as shown below. This result no doubt reflects the strain (and synthetic challenge)

Org Lett. Author manuscript; available in PMC 2008 September 22. 
imposed by the encumbered $\mathrm{C}(12)$ quaternary carbon since the electrocyclic rearrangements of model systems lacking substituents at this position proceeded uneventfully.

(11). This fortuitous transformation most likely proceeds through the $\alpha$-phenylselenyl $\alpha$-haloketone. For the halogenation of an $\alpha$-phenylselenyl ketone, seeTsuda Y, Hosoi S. Chem. Pharm. Bull 1985;33:1745.

(12)(a). Ghaffar T, Parkins AW. Tetrahedron Lett 1995;36:8657. (b) Ghaffar T, Parkins AW. J. Mol. Catal. A 2000;160:249.(c) For another application of this catalyst in an equally complex setting, seeHerzon SB, Myers AG. J. Am. Chem. Soc 2005;127:5342. [PubMed: 15826171]

(13)(a). Baumgarten HE, Staklis A. J. Am. Chem. Soc 1965;87:1141. (b) Baumgarten HE, Smith HL, Staklis A. J. Org. Chem 1975;40:3554.

Org Lett. Author manuscript; available in PMC 2008 September 22. 
<smiles>C=C[C@H]1C(NC)=C2[C@H](CC1Cl)C(C)(C)[C@]21C(=O)Nc2ccccc21</smiles>

welwitindolinone $A$

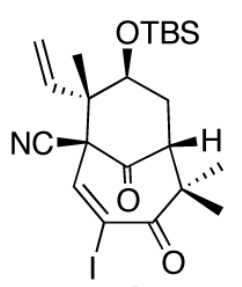
4<smiles>[CH]=C</smiles>

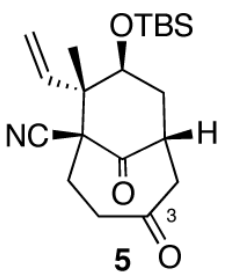<smiles>C#CC#C</smiles>
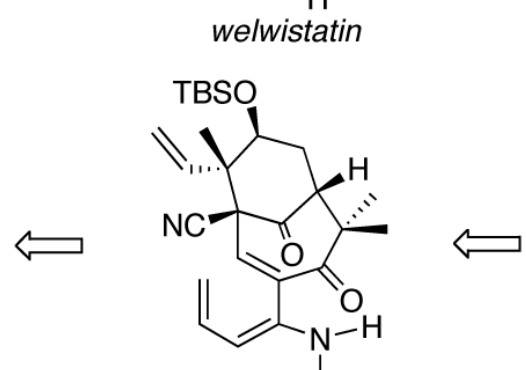<smiles>C=C[C@]1(C)C(O)=C[C@H](C)[C@H](C)[C@H]1OCc1c[nH]c2ccccc12</smiles><smiles>C[AsH3-]</smiles>
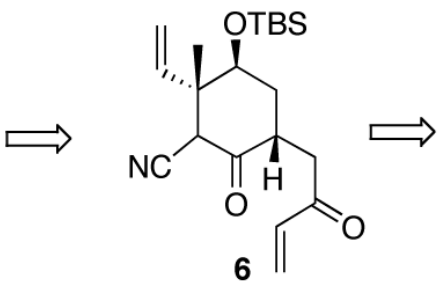<smiles>C=C[C@]1(O)CC(=O)C[CH+]C[C@@H]1O[SnH3]</smiles>

Scheme 1.

Org Lett. Author manuscript; available in PMC 2008 September 22. 

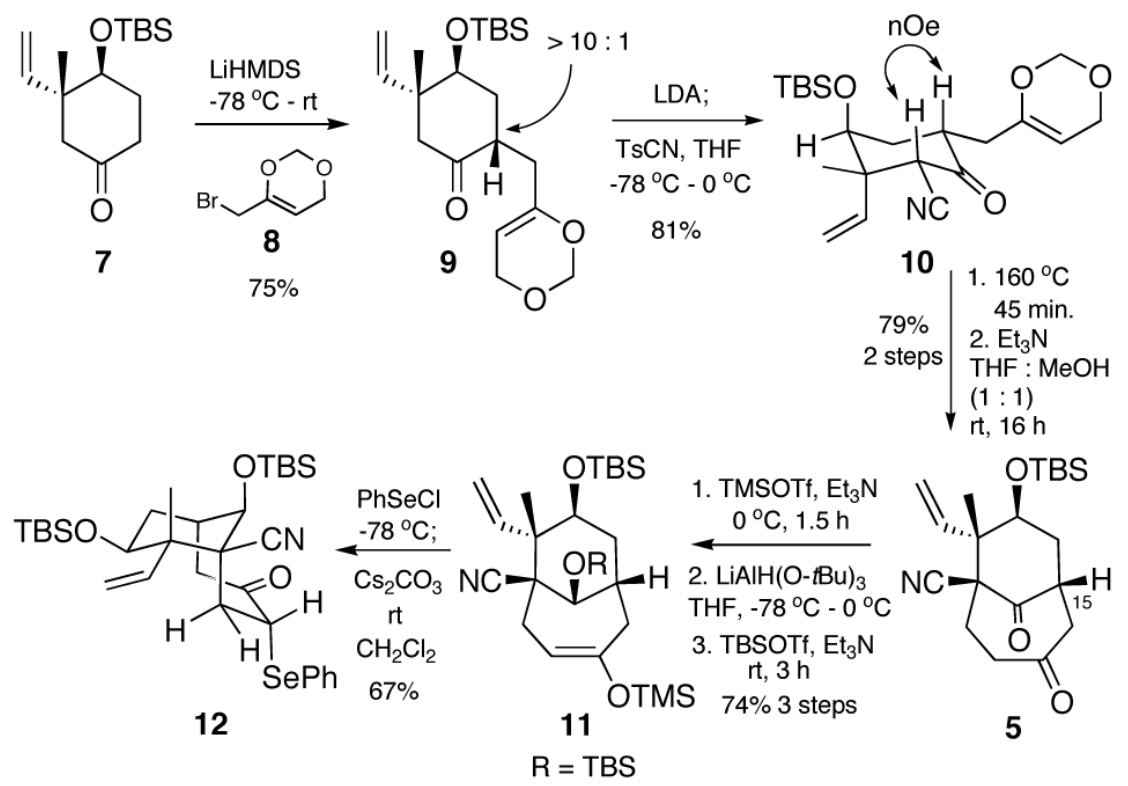

Scheme 2.

Org Lett. Author manuscript; available in PMC 2008 September 22. 

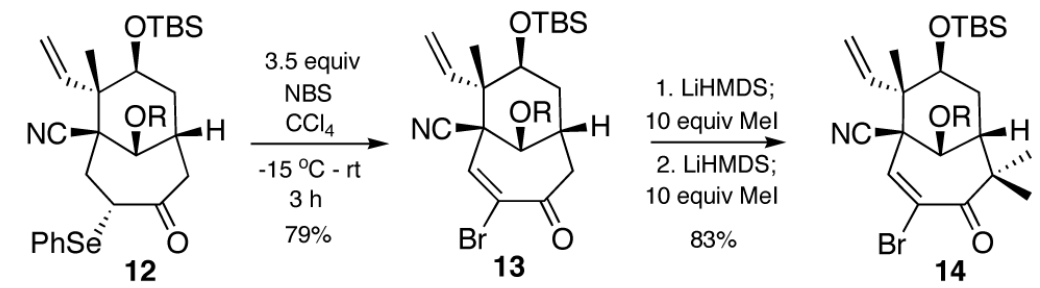

$$
\mathrm{R}=\mathrm{TBS}
$$
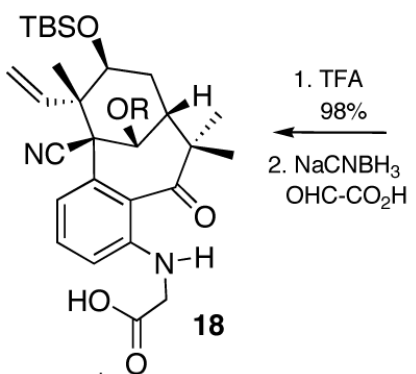

TBSO
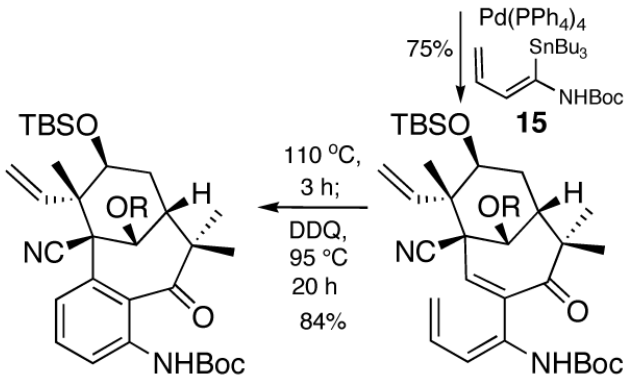

17

16
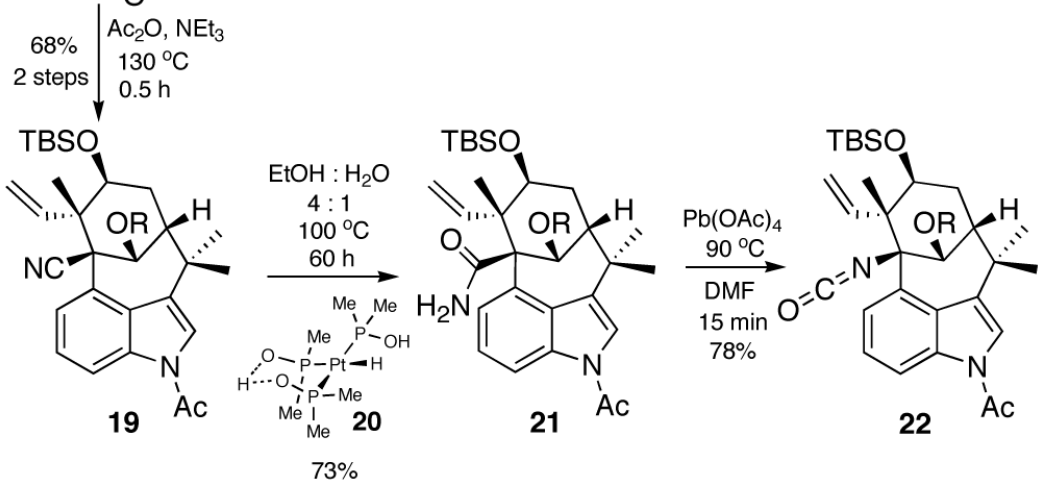

Scheme 3.

Org Lett. Author manuscript; available in PMC 2008 September 22. 